\title{
FOREIGN DIRECT INVESTMENT LAW IN ASEAN COUNTRIES: PROSPECT FOR ASEAN ECONOMIC COMMUNITY
}

\author{
Mohamad Hanapi bin Mohamad, \\ College of Law, Government and International Studies Universiti Utara Malaysia \\ E-mail:mhm177@uum.edu.my
}

\begin{abstract}
The development of ASEAN towards the establishment of ASEAN Economic Community (AEC) at the end of 2015 has brought into sharp focus on the issue of economic and financial integration in the region. The ASEAN region has been the largest recipient of FDI, relative to GDP in Asia Pacific. Between 1952 and 2012, Singapore accounts for more than half of total FDI to the whole region. Thailand ranks the second with a 13 percent share, followed by Indonesia, Malaysia, Vietnam and the Philippines which account between 13 to 8 percent. Foreign direct investment into ASEAN recovered from the world economic crisis and regained its 2007 level of USD 76 thousand million in 2010. ASEAN Dialogue Partners comprising EU, USA and Japan accounted USD 64 thousand million, while the share of Intra-ASEAN in this total was $16 \%$ which indicates the progress of ASEAN integration. Theories of economic integration and market liberalization have been used to explain the role of foreign direct investment in developing countries. This paper aims to examine ASEAN's financial integration prospects. ASEAN integration could accelerate in the years ahead with enhancing financial infrastructure and reliable flexible policy frameworks. On the long term closer engagement among member countries could potentially increase real incomes and accelerate real convergence.
\end{abstract}

Keywords : ASEAN, Foreign Direct Investment, financial integration prospect

\section{A. INTRODUCTION}

The Association of Southeast Asian Nations (ASEAN) consists of diverse group of ten fastest growing economies at different stages of development. The members are Brunei, Cambodia, Indonesia, Lao P.D.R, Malaysia, Myanmar, Philippines, Singapore, Thailand and Vietnam. ASEAN is home to more than 610 million people, of whom about 100 million live below the poverty line. In its early days, the primary focus of ASEAN was on reducing geopolitical tensions in the region. In 2003, ASEAN leaders decided to establish an ASEAN Economic Community (AEC). Amid growing concerns about the ASEAN region's perceived loss of competitiveness to China and India, there was a strong desire to enhance the region's role against the backdrop of a proliferation of free trade agreements between ASEAN and its trade

Yustisia Volume 8 Number 1 (January-April 2019)

Foreign Direct Investment Law ...

(C)2019; This is an Open Acces Research distributed under the term of the Creative Commons Attribution Licencee (https://Creativecommons.org/licences/by/4.0), which permits unrestricted use, distribution, and reproduction in any medium, provided the original works is properly cited. 
partners. Accordingly, in 2007 ASEAN leaders agreed on an integrated AEC by enhancing intraregional connectivity in areas such as trade, investment, tourism, and development.

The AEC has set four main targets: (i) fostering a single market and production base with free flow of goods, services, investments, and skilled labor, and free flow of capital within ASEAN; (ii) developing a highly competitive economic region nurturing fair competition, consumer protection, intellectual property rights, and infrastructure development; (iii) attaining equitable economic development by strengthening SMEs and (iv) achieving ever greater integration into global economy. The main domain of intraregional connectivity comes from FDI flows to fulfil the dreams of its populations who are young and growing and have high saving rates. But investment needs are also large, related to advancing urbanization, the region's growing middle class, and the need to increase connectivity and provide hard and soft infrastructure. Coming out of the Asian financial crisis, ASEAN countries have made great strides in strengthening their macroeconomic frameworks and their external positions. The region has witnessed an increase in trade and capital flows, both within the region and with the rest of Asia and the world.

Foreign direct investment (FDI) has been playing an increasingly important role and is recognized to contribute to benefits of economic and social development of many economies of the world. FDI has significantly contributed into the industrialization and development of manufacturing sector in the developing ASEAN countries. Foreign direct investments by multinational firms were still the major contributor to FDI inflows into ASEAN. FDI inflows stood at USD 120 billion in 2015 though slightly lower than previous year but still remained a significant recipients of FDI flows in 2015 which is $16 \%$ of global FDI flows to developing economies (ASEAN Investment Report, 2016).

The contours of FDI flows and MNE development for ASEAN Economic Community were reflected from a wide range of activities. Service sectors were predominantly in Finance such as Intracompany Loans and Cross-border M\&As. This sector accounted to almost USD 80 billion while manufacturing rose from USD 18 billion to USD 29 billion in 2015 .

Similar progress can be seen in the equity component of FDI flows. Multinational companies continue to expand their operation in the region as well as across ASEAN with regionally integrated operations and investment in multiple countries. The equity capital from multinational companies were at all-time high in 2015 with the total value at USD 96 billion or $82 \%$ of all inward FDI in the region while the others are $17 \%$ from reinvested earnings and $1 \%$ from loans.

The development of FDI flows into ASEAN also demonstrated progress on the key initiatives by the respective governments towards ASEAN Economic 
Community. Asian investors continue to dominate the FDI landscape in new members of ASEAN. ASEAN, China, Republic of Korea and Japan played important roles in these countries. Vietnam, Myanmar, Lao P.D.R and Cambodia showed a rise of 38 $\%$ or USD 17 billion of FDI flows in 2015. The bulk of these inward flows were in manufacturing in Vietnam and Myanmar while infrastructure continues to dominate in Lao P.D.R and financial services in Cambodia.

ASEAN Economic Community has progressed. Direct investment has risen; cross border banking linkages have deepened and foreign participation in ASEAN capital markets has increased.

\section{B. PROBLEM STATEMENT}

This paper attempts to identify ASEAN market integration and its prospects. Market integration in ASEAN could accelerate in the years ahead, including the establishment of the ASEAN Economic Community. This will be done in a gradual long term process, in particular taking into consideration of the "ASEAN way" of consensus decision-making. It provides a critical review of the AEC agenda, the pattern of international involvement of the ASEAN firms in the future given the recurring complexity and dynamism of international business.

\section{RESEARCH METHOD}

The research is a normative legal research (doctrinal research). It used a qualitative analysis and legislation approaches. Thus, the choice of relevant material and integrated interpretation during interviews with stakeholders related to the main research issues

\section{DISCUSSION AND RESEARCH RESULT}

\section{Growth, Trade Integration in ASEAN}

Historically, international business activity initially took in the form of exporting and importing. Exporting is the selling of products made in one's own country for use or resale in other country. Importing is the buying of products made in other countries for use or resale in one's own country. Table 1.0 presents a number of comparisons between international trade flows during in the post-World War II period and those that have been occurring most recently. For instance, world trade flows were recorded at USD 62 billion in 1948 and maintained a fairly progressive growth in their aggregate trade flows up until 1970s. By 1983, world trade flows was USD 594 billion and by 2014, world trade recorded at USD 18494 billion. The United States in particular maintained as the major player 
in international trade but China took over as the main exporter in 2014 having share of $12.3 \%$ of world total export while US still dominating world importer, China had increased her share of world total import of $10.3 \%$ (WTO, 2015)

Table 1.0

\section{World Merchandise Exports by Region}

\begin{tabular}{|c|c|c|c|c|c|c|c|c|}
\hline \multirow{2}{*}{\multicolumn{9}{|c|}{$\begin{array}{l}\text { World merchandise exports by } \\
\text { (Bilion dollars and percentige) }\end{array}$}} \\
\hline & & & & & & & & \\
\hline & 1948 & 1953 & 1963 & 1973 & 1983 & 1993 & 2003 & 2014 \\
\hline & \multicolumn{8}{|c|}{ Value } \\
\hline \multirow[t]{2}{*}{ World } & 59 & 84 & 157 & 579 & 1838 & 3688 & 7380 & 18494 \\
\hline & \multicolumn{8}{|c|}{ Share } \\
\hline World & 100.0 & 100.0 & 100.0 & 100.0 & 100.0 & 100.0 & 100.0 & 100.0 \\
\hline North America & 28.1 & 24.8 & 19.9 & 17.3 & 16.8 & 17.9 & 15.8 & 13.5 \\
\hline United States & 21.7 & 18.8 & 14.9 & 12.3 & 11.2 & 12.6 & 9.8 & 8.8 \\
\hline Canada & 5.5 & 5.2 & 4.3 & 4.6 & 4.2 & 3.9 & 3.7 & 2.6 \\
\hline Mexico & 0.9 & 0.7 & 0.6 & 0.4 & 1.4 & 1.4 & 2.2 & 2.1 \\
\hline South and Central America & 11.3 & 9.7 & 6.4 & 4.3 & 4.5 & 3.0 & 3.0 & 3.8 \\
\hline Brazil & 2.0 & 1.8 & 0.9 & 1.1 & 1.2 & 1.0 & 1.0 & 1.2 \\
\hline Venezuela, Bolivarian Rep. of & 1.5 & 1.7 & 1.5 & 0.6 & 0.8 & 0.4 & 0.4 & 0.4 \\
\hline Europe & 35.1 & 39.4 & 47.8 & 50.9 & 43.5 & 45.3 & 45.9 & 36.8 \\
\hline Germany a & 1.4 & 5.3 & 9.3 & 11.7 & 9.2 & 10.3 & 10.2 & 8.2 \\
\hline Netherlands & 2.0 & 3.0 & 3.6 & 4.7 & 3.5 & 3.8 & 4.0 & 3.6 \\
\hline France & 3.4 & 4.8 & 5.2 & 6.3 & 5.2 & 6.0 & 5.3 & 3.2 \\
\hline Italy & 1.8 & 1.8 & 3.2 & 3.8 & 4.0 & 4.6 & 4.1 & 2.9 \\
\hline Commonwealth of Independent States (CIS) b & - & - & - & - & - & 1.5 & 2.6 & 4.0 \\
\hline Africa & 7.3 & 6.5 & 5.7 & 4.8 & 4.5 & 2.5 & 2.4 & 3.0 \\
\hline South Africa c & 2.0 & 1.6 & 1.5 & 1.0 & 1.0 & 0.7 & 0.5 & 0.5 \\
\hline Middle East & 2.0 & 2.7 & 3.2 & 4.1 & 6.7 & 3.5 & 4.1 & 7.0 \\
\hline Asia & 14.0 & 13.4 & 12.5 & 14.9 & 19.1 & 26.0 & 26.1 & 32.0 \\
\hline China & 0.9 & 1.2 & 1.3 & 1.0 & 1.2 & 2.5 & 5.9 & 12.7 \\
\hline Japan & 0.4 & 1.5 & 3.5 & 6.4 & 8.0 & 9.8 & 6.4 & 3.7 \\
\hline India & 2.2 & 1.3 & 1.0 & 0.5 & 0.5 & 0.6 & 0.8 & 1.7 \\
\hline Australia and New Zealand & 3.7 & 3.2 & 2.4 & 2.1 & 1.4 & 1.4 & 1.2 & 1.5 \\
\hline Six East Asian traders & 3.4 & 3.0 & 2.5 & 3.6 & 5.8 & 9.6 & 9.6 & 9.6 \\
\hline \multicolumn{9}{|l|}{ Memorandum item: } \\
\hline EU d & - & - & 24.5 & 37.0 & 31.3 & 37.3 & 42.4 & 33.3 \\
\hline USSR, Former & 2.2 & 3.5 & 4.6 & 3.7 & 5.0 & - & - & - \\
\hline GATT/WTO Members e & 63.4 & 69.6 & 75.0 & 84.1 & 77.0 & 89.0 & 94.3 & 97.3 \\
\hline \multicolumn{9}{|c|}{ a Figures refer to the Fed. Rep. of Germany from 1948 through 1983.} \\
\hline \multirow{2}{*}{\multicolumn{9}{|c|}{$\begin{array}{l}\text { b Figures are significantily affected by incluaing the mutual trade fows of the Batic States and the CIS between } 1993 \text { and } 2003 . \\
\text { c Beginning with } 1998 \text {, figures refere to South Africa ony and no longer to the Sourhem African Customs Union. }\end{array}$}} \\
\hline & & & & & & & & \\
\hline \\
\hline & & & & & & & & \\
\hline \multicolumn{9}{|c|}{$\begin{array}{l}\text { E Membership as of the year stated } \\
\text { Note: Beween } 1973 \text { and } 1983 \text { and between } 1993 \text { and } 2003 \text { export shares were sigrifcarty infuenced by oi price developnents. }\end{array}$} \\
\hline
\end{tabular}

Another interesting feature of global trade is the expanding volume of trade in various highly aggregated industrial sectors. The huge shift was shown in the composition of trade in the 1980s toward manufacturing goods and in 1990s toward minerals and away from other industries. Trade in minerals accounted for about 17 percent of the total trade in 1980s, but for about 30 percent of the total trade in 1990s, after the two major OPEC price hikes. Manufacturing decreased from about 61 percent of total exports in 1970 to about 55 percent of the total export in 1980. The original relationship was approximately re-established in 1985, due to the oil price decline, and it continues until present (WTO, 2015). 
The second major form of international business activity is international investments. International investment is movement of capital which is supplied by residents of one country to residents of another country. This type of investment is divided into two major categories (Mohamad, Mohamad Hanapi 2012). The first type is foreign direct investment (FDI). Foreign direct investment is investment made for the purpose of actively controlling property, assets, or companies located in host countries. The stock of foreign direct investment stood at USD 1.23 trillion in 2014 (Table 6.0, UNCTAD, 2015). Traditionally, United States accounted for about half of the total investment during the period after World War II, however the total investment declined to less than 40 percent by 1983 . After rebuilding their economies from war damage, both German and Japanese firms showed the most rapid growth in FDI during the post-war period. In fact, both of the traditional powers of the early $20^{\text {th }}$ century, the United States and United Kingdom, shown a decline in their shares of global FDI, though firms from both countries continue to invest abroad and their FDI shares still lead compare to those of other countries. FDI undertaken by less developed countries accounted for less than 10 percent of the total investment reported during the period. In terms of major economics areas, the industrialized countries dominate world trade, accounting for about 68 percent of world trade in recent years. Details of trade on a regional basis are provided in Table 2.0 and 3.0.

Table 2.0

\section{World Merchandise Imports by Region}

\begin{tabular}{|c|c|c|c|c|c|c|c|c|}
\hline $\begin{array}{l}\text { Table } 1.6 \\
\text { World merchandise imports by re }\end{array}$ & eted eco & omy, 1948 & 1953,196 & 1973,19 & 1993,20 & 3 and 201 & & \\
\hline \multicolumn{9}{|l|}{ (Billion dollars and percentage) } \\
\hline & 1948 & 1953 & 1963 & 1973 & 1983 & 1993 & 2003 & 2014 \\
\hline & \multicolumn{8}{|c|}{ Value } \\
\hline \multirow[t]{2}{*}{ World } & 62 & 85 & 164 & 594 & 1883 & 3805 & 7696 & 18641 \\
\hline & \multicolumn{8}{|c|}{ Share } \\
\hline World & 100.0 & 100.0 & 100.0 & 100.0 & 100.0 & 100.0 & 100.0 & 100.0 \\
\hline North America & 18.5 & 20.5 & 16.1 & 17.2 & 18.5 & 21.3 & 22.4 & 17.7 \\
\hline United States & 13.0 & 13.9 & 11.4 & 12.3 & 14.3 & 15.9 & 16.9 & 12.9 \\
\hline Canada & 4.4 & 5.5 & 3.9 & 4.2 & 3.4 & 3.7 & 3.2 & 2.5 \\
\hline Mexico & 1.0 & 0.9 & 0.8 & 0.6 & 0.7 & 1.8 & 2.3 & 22 \\
\hline South and Central America & 10.4 & 8.3 & 6.0 & 4.4 & 3.9 & 3.3 & 2.5 & 4.0 \\
\hline Brazil & 1.8 & 1.6 & 0.9 & 1.2 & 0.9 & 0.7 & 0.7 & 1.3 \\
\hline Chile & 0.4 & 0.4 & 0.4 & 0.2 & 0.2 & 0.3 & 0.3 & 0.4 \\
\hline Europe & 45.3 & 43.7 & 52.0 & 53.3 & 44.1 & 44.5 & 45.0 & 36.4 \\
\hline Germany a & 2.2 & 4.5 & 8.0 & 9.2 & 8.1 & 9.0 & 7.9 & 6.5 \\
\hline United Kingdom & 13.4 & 11.0 & 8.5 & 6.5 & 5.3 & 5.5 & 5.2 & 3.7 \\
\hline France & 5.5 & 4.9 & 5.3 & 6.4 & 5.6 & 5.7 & 5.2 & 3.6 \\
\hline Netherlands & 3.4 & 3.3 & 4.4 & 4.8 & 3.3 & 3.3 & 3.4 & 3.2 \\
\hline Commonwealth of Independent States (CIS) b & - & . & - & - & - & 1.2 & 1.7 & 2.7 \\
\hline Africa & 8.1 & 7.0 & 5.2 & 3.9 & 4.6 & 2.6 & 2.2 & 3.4 \\
\hline South Africa c & 2.5 & 1.5 & 1.1 & 0.9 & 0.8 & 0.5 & 0.5 & 0.7 \\
\hline
\end{tabular}




\begin{tabular}{lrrrrrrrr} 
Middle East & 1.8 & 2.1 & 2.3 & 2.7 & 6.2 & 3.3 & 2.8 & 4.2 \\
\hline Asia & 13.9 & 15.1 & 14.1 & 14.9 & 18.5 & 23.5 & 23.5 & 31.5 \\
$\quad$ China & 0.6 & 1.6 & 0.9 & 0.9 & 1.1 & 2.7 & 5.4 & 10.5 \\
\hline Japan & 1.1 & 2.8 & 4.1 & 6.5 & 6.7 & 6.4 & 5.0 & 4.4 \\
\hline India & 2.3 & 1.4 & 1.5 & 0.5 & 0.7 & 0.6 & 0.9 & 2.5 \\
\hline Australia and New Zealand & 2.9 & 2.3 & 2.2 & 1.6 & 1.4 & 1.5 & 1.4 & 1.5 \\
\hline Six East Asian traders & 3.5 & 3.7 & 3.2 & 3.9 & 6.1 & 10.2 & 8.6 & 9.4 \\
\hline Memorandum item: & & & & & & & & \\
$\quad$ EU d & - & - & 25.5 & 37.1 & 31.4 & 36.2 & 41.3 & 32.9 \\
\hline USSR, Former & 1.9 & 3.3 & 4.3 & 3.6 & 4.3 & - & - & - \\
\hline GATTWTO Members e & 58.6 & 66.9 & 75.3 & 85.5 & 79.7 & 89.3 & 96.0 & 97.7 \\
\hline
\end{tabular}

a Figures refer to the Fed. Rep. of Germany from 1948 through 1983.

b Figures are significantly affected by incluing the muthel trate fous of the Batic States and the CIS between 1993 and 2003

c Beginning with 1998, figures refere to South Africa onily and no longer to the Sourhem African Customs Union.

d Figures refer to the EEC(6) in 1963, EC(9) in 1973, EC(10) in 1983, EU(12) in 1993, EU(25) in 2003 and EU(28) in 2014.

Note: Bewween 1973 and 1983 and bewwen 1993 and 2003 export shares were significantly infuenced by ol price developnents.

Table 3.0

Intra and Inter-regional Merchandise Trade

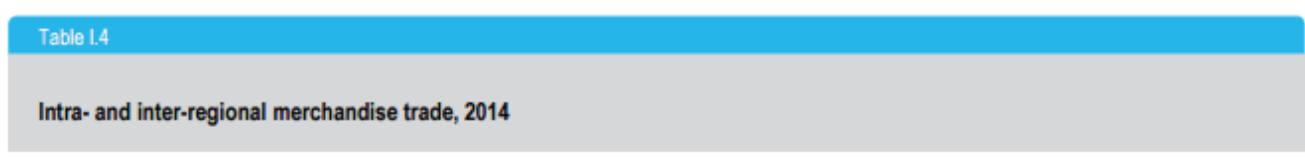

(Bilion dollers and percentage)

\begin{tabular}{|c|c|c|c|c|c|c|c|c|}
\hline \multirow[b]{2}{*}{ Origin } & \multicolumn{8}{|c|}{ Destination } \\
\hline & $\begin{array}{l}\text { North } \\
\text { America }\end{array}$ & $\begin{array}{l}\text { South and } \\
\text { Central } \\
\text { America }\end{array}$ & Europe & CIS & Africa & Middle East & Asia & World \\
\hline \multicolumn{9}{|l|}{ Value } \\
\hline World & 3195 & 744 & 6792 & 512 & 639 & 780 & 5485 & 18494 \\
\hline North America & 1251 & 214 & 379 & 17 & 43 & 79 & 504 & 2493 \\
\hline South and Central America & 173 & 179 & 114 & 9 & 18 & 17 & 170 & 695 \\
\hline Europe & 540 & 119 & 4665 & 218 & 221 & 229 & 738 & 6810 \\
\hline Commonwealth of Independent States (CIS) & 28 & 7 & 385 & 131 & 16 & 22 & 134 & 735 \\
\hline Africa & 39 & 29 & 201 & 2 & 98 & 18 & 152 & 555 \\
\hline Middle East & 99 & 11 & 148 & 7 & 36 & 113 & 694 & 1288 \\
\hline Asia & 1065 & 185 & 900 & 127 & 207 & 302 & 3093 & 5917 \\
\hline \multicolumn{9}{|c|}{ Share of regional trade flows in each region's total merchandise exports } \\
\hline World & 17.3 & 4.0 & 36.7 & 2.8 & 3.5 & 4.2 & 29.7 & 100.0 \\
\hline North America & 50.2 & 8.6 & 15.2 & 0.7 & 1.7 & 3.2 & 20.2 & 100.0 \\
\hline South and Central America & 24.8 & 25.8 & 16.4 & 1.4 & 25 & 2.4 & 24.5 & 100.0 \\
\hline Europe & 7.9 & 1.7 & 68.5 & 3.2 & 3.3 & 3.4 & 10.8 & 100.0 \\
\hline Commonwealth of Independent States (CIS) & 3.9 & 0.9 & 524 & 17.8 & 21 & 3.1 & 18.2 & 100.0 \\
\hline Africa & 7.0 & 5.1 & 36.2 & 0.4 & 17.7 & 3.3 & 27.3 & 100.0 \\
\hline Middle East & 7.7 & 0.8 & 11.5 & 0.5 & 28 & 8.8 & 53.9 & 100.0 \\
\hline Asia & 18.0 & 3.1 & 15.2 & 21 & 3.5 & 5.1 & 52.3 & 100.0 \\
\hline \multicolumn{9}{|c|}{ Share of each region's exports in world merchandise exports to the region } \\
\hline World & 100.0 & 100.0 & 100.0 & 100.0 & 100.0 & 100.0 & 100.0 & 100.0 \\
\hline North America & 39.2 & 28.8 & 5.6 & 3.4 & 6.8 & 10.1 & 9.2 & 13.5 \\
\hline South and Central America & 5.4 & 24.1 & 1.7 & 1.8 & 28 & 2.2 & 3.1 & 3.8 \\
\hline Europe & 16.9 & 16.0 & 68.7 & 42.6 & 34.7 & 29.4 & 13.5 & 36.8 \\
\hline Commonwedth of Independent States (CIS) & 0.9 & 0.9 & 5.7 & 25.6 & 24 & 2.9 & 2.4 & 4.0 \\
\hline Africa & 1.2 & 3.8 & 3.0 & 0.4 & 15.4 & 2.3 & 2.8 & 3.0 \\
\hline Mddle East & 3.1 & 1.5 & 22 & 1.3 & 5.6 & 14.5 & 12.7 & 7.0 \\
\hline Asia & 33.3 & 24.9 & 13.2 & 24.7 & 32.4 & 38.7 & 56.4 & 32.0 \\
\hline \multicolumn{9}{|c|}{ Share of regional trade flows in world merchandise exports } \\
\hline World & 17.3 & 4.0 & 36.7 & 2.8 & 3.5 & 4.2 & 29.7 & 100.0 \\
\hline North America & 6.8 & 1.2 & 2.0 & 0.1 & 0.2 & 0.4 & 2.7 & 13.5 \\
\hline South and Central America & 0.9 & 1.0 & 0.6 & 0.1 & 0.1 & 0.1 & 0.9 & 3.8 \\
\hline Europe & 2.9 & 0.6 & 25.2 & 1.2 & 1.2 & 1.2 & 4.0 & 36.8 \\
\hline Commonwealth of Independent States (CIS) & 0.2 & 0.0 & 2.1 & 0.7 & 0.1 & 0.1 & 0.7 & 4.0 \\
\hline Africa & 0.2 & 0.2 & 1.1 & 0.0 & 0.5 & 0.1 & 0.8 & 3.0 \\
\hline Middle East & 0.5 & 0.1 & 0.8 & 0.0 & 0.2 & 0.6 & 3.8 & 7.0 \\
\hline Asia & 5.8 & 1.0 & 4.9 & 0.7 & 1.1 & 1.6 & 16.7 & 32.0 \\
\hline
\end{tabular}

52 Yustisia Volume 8 Number 1 (January-April 2019)

Foreign Direct Investment Law ... 
These tables also show the relative importance of the European Union, the United States and Japan in terms of both imports and exports. Among the developing countries the tables show Asia accounts for well over one-half of their imports and exports, while the Western. Hemisphere and the Middle East each account for 15 percent or less of developing country trade.

In the case of the Association of Southeast Asian Nations (ASEAN) which has a population of about 610 million people, the transformation of global trade which had occurred in the developed countries over the decades, had also found considerable impact on their economies. As ASEAN is moving towards a comprehensive single market by 2020, ASEAN countries have been restructuring their economies by adopting economic policies that have fostered exports and inward foreign investment. The fluctuation in commodity prices and the expanding markets of United States and European Union compelled countries ASEAN members that had been dependent on those products for export revenue, to promote more diversity in their economic structure. Structural change has transformed their economic profiles from being exporters of agricultural commodities and unprocessed goods to become exporters of light manufactured goods. Besides, Northeast Asian investment has contributed to Southeast Asia rapid growth in order to take advantage of its large supply of cheap labor to manufacture goods. The ASEAN economies of Singapore, Malaysia, Thailand, Philippines and Indonesia have benefited most. Table 4.0 and Table 5.0 provide data on total trade of ASEAN countries. Total trade for ASEAN was recorded at USD 2523 billion while the flow of capital stock was $2.8 \%$ of the total foreign direct investment flow. (UNCTAD, 2015) In Malaysia, inflows of foreign direct investment have contributed around 20 percent of gross domestic capital formation and provided access to improved technological production and export markets.

Economic growth and geopolitical development in the Southeast Asia is a new trend in ASEAN. While economic growth is projected to grow moderately at $6 \%$ throughout this decade, another interesting feature is the growing middle class in ASEAN could also drive more FDI into ASEAN (WTO, 2015 and IMF, 2016) The Philippines has surpassed the difficult years of the 1980s and 1990s and in the process of attaining modest economic recovery (WTO, 2015). The peaceful presidential election will rebuilt the people's confidence in political stability and effective economic management. Foreign investment will pour in to take advantage of cheap labour. The structural reforms implemented in recent years and the lifting of the import levy should also help to stimulate the economy. However, the success of the economic recovery will also be heavily dependent upon improvement on the shortage of electricity and other physical infrastructure. 
Therefore, once the government is able to overcome these constraints, continuous rapid growth is expected to take place into the next decade.

If there is no further major political crisis, the growth momentum of Thailand is expected to be maintained over the next few years though at lower rates than in the previous years. The major stimulus to growth will continue to come from export of goods and services along with an increase in private and public investment in transportation and communications. However, the shortage of skilled workers coupled with the infrastructural bottlenecks could adversely affect the inflow of foreign investment and could exert upward pressure on inflation.

In Malaysian, the economic growth continued to register positive growth. Domestic demand has become a more important force in the economy as incomes rise gradually. New inflows of foreign direct investment may be achieved by measures such as special levy on foreign workers in key economic sectors and the implementation of good and service tax.

The prospect for the Singapore economy remain bright with average growth of $4.5 \%$ and the manufacturing and service sectors, namely, the financial business will remain as major contributors to the rapid growth. In the case of Indonesia, the country potential growth prospect for the future years also remains bright. The worries on 2015 national elections were over and the government is now seriously concentrating on improving the management of the economy. Contribution from the non-oil sector should remain the major source of growth.

Several factors have contributed to the growth of international business: market expansion, resource acquisition, competitive forces, technological changes, and changes in government trade and investment policies. Market expansion is the most significant catalyst for international business growth. As the productive capacities of firms' factories outgrow the size of their home markets, firm often internationalize their operations to seek new marketing opportunities. In many smaller market economies, such as Singapore, Switzerland and Netherlands, firms quickly recognized that they had to look beyond national boundaries if they were to continue to grow. The home country market is too small, took Nestle to start shipping milk to 16 different countries as early as 1875 .

Competitive forces also spur growth in international business activity. Because of economies of scale and the financial strength that comes with larger organizational size, smaller firms often have difficulty competing with larger ones. Thus, when a firm's competitors begin to grow by expanding into new foreign markets, the other firm may have little choice but to follow suit. For example in the late 1990s, Heinz, a US food processing firm, decided to increase its international presence because the company felt the need to keep up with its primary competitors such Nestle, Kellogg, and Philip Morris by setting up 
operations in several foreign markets.

Technological changes- particularly in communications, transportation, and information processing are other important drivers of the growth in international business activities. The increasing usage of computers to rapidly handle and process vast quantities of information allows firms to manage offices and factories located in every corner of the globe. Changes in communications technology, such as the manager in Tokyo office will be able to receive reports from colleagues in Amsterdam, Abidjan, and Auckland in minutes rather than days. These technological advance equipment make managing a business far easier today than in the past and hence have facilitated expansion into international, markets.

Finally, changes in government trade and investment policies have expanded growth opportunities for international businesses. Economic liberalization measures in many countries in the region saw the structural changes in their economies. In the past 40 years, countries have negotiated reductions in imports tariffs and eliminated barriers to FDI within their borders. Many of the reductions were negotiated through World Trade Organization (WTO) agreements and more recently Trans Pan Pacific Agreement (TPPA) and the many other multilateral trade negotiations. To date many of the international trade discussions were turned into agreements which consequently saw the expansion of international businesses which have become more important to the world's economy.

\section{Foreign Direct Investment and ASEAN Single Market}

There is much support from ASEAN governments for ASEAN Economic Community (AEC). Indeed since its first inception in 1967, they have embraced regional collaboration as an important component of their development strategies and concluded a very large number of regional integration arrangements. Traditionally US, European Union and Japan were ASEAN most important trade, investment and development partner. Trade with these countries was governed by series of conventions which granted ASEAN countries preferential access to these markets. In its early days, the primary focus of ASEAN was on reducing geopolitical tensions in the region.

At the macro level, the AEC paradigm is that of linear market integration, following stepwise integration of goods, labor and capital markets, and eventually monetary and fiscal integration. The starting point is usually a free trade area, followed by accustom union, a common market and then the integration of monetary and fiscal matters to establish an economic union. The achievement of political union features the ultimate objective in ASEAN Regional Integration Arrangements. This process is followed by setting ASEAN Economic Community. In 2003, the ASEAN leaders agreed for the establishment of ASEAN 
Economic Community and several initiatives were put forward in realizing a single market goal. In 2010, ASEAN leaders adopted the Master Plan on ASEAN Connectivity. The objective is to facilitate the establishment of the AEC by 2015 by enhancing regional connectivity in areas such as trade, investment, tourism and development. ASEAN Connectivity comprises three main elements: (i) enhancing Physical Connectivity by improving transportation, information and communication technology (ICT), and energy infrastructure;(ii) improving institutional Connectivity by setting up procedures to facilitate international transactions of goods and services, and cross-border movement of skilled workers and (iii) strengthening Peopleto-People Connectivity through socio-cultural initiatives such as education and tourism within ASEAN.

Several initiatives have been taken to enhance cross-border collaboration among the various capital markets in ASEAN, including by building capacity and infrastructure. The working Committee on Capital Account Liberalization was established to monitor the implementation of priority actions order to achieve freer flow of capital in the region as per AEC Blueprint. The ASEAN Capital Markets Forum (ACMF) focuses on the harmonization of domestic laws and regulation and the development of market infrastructure with a view to integrate the region's equities market. In 2010, ASEAN Central Bank Governors endorsed the creation of the Working Committee on Payment and Settlement System (WCPSS) which focuses on policy, legal frameworks, instruments, institutions and market infrastructure. In April 2011, ASEAN Central Bank Governors endorsed the creation of the Task Force on ASEAN Banking Integration Framework (ABIF), which aims to achieve ASEAN-wide banking sector liberalization by 2020. The ASEAN Capital Market Infrastructure (ACMI) Blueprint was developed in 2013. Accordingly the Working Committee on Capital Market Development aims to enable ASEAN issuers and investors to access cross-border ASEAN equity and bond markets through integrated access, clearing, custody and settlement systems and arrangements.

The geopolitical configuration of ASEAN has been largely deter4mined by the countries colonial powers, and as such has impact on the emergence of nation states. Small domestic markets and market fragmentation translates into lack of scale economies in the production and distribution of goods and services. The immediate post-establishment era of ASEAN was characterized by initially a strong commitment to peace and neutrality for the region but later giving more emphasis to economic planning. Underpinning this policy approach was the belief that development would be promoted by industrialization, in particular core manufacturing. The industrialization-regional integration interface was 
clear. Larger, protected market AFTA was formed in the various industries. The aim was to establish a broad range of industries across different sectors.

At the firm level, a firm seeking to enter a foreign market must make an important strategic decision on which entry mode to use for the market. Normative decision theory suggest that the choice of a foreign market entry mode should be based on trade-offs between risk and returns. A firm is expected to choose the entry mode that offers the highest risk-adjusted return on investment. However, behavioral evidence indicates that a firm's choices may also be determined by resource availability and need for control (Stopford and Wells, 1972). Resource availability refers to the financial and managerial capacity of firm for serving a particular foreign market. Control refers to a firm's need to influence systems, methods and decisions in that foreign market (Anderson and Gatigon, 1986). Control is desirable to improve a firm's competitive position and maximize the returns on its assets and skills. Higher operational control results from having greater ownership in the foreign venture. In environments characterized by high investment risks, firms with valuable assets and skills may be able to bargain with host governments for concessions that provide immunity against investment risks. Ownership advantage of proprietary product or technology is fairly evident among multinational firms investing in ASEAN markets and formed the competitive advantage over its industry rival (Mohamad, Mohamad Hanapi 2012). These firm-specific ownership advantages may be tangible or intangible. For example, the ownership by Japanese, Korean and European automobile companies such as Toyota, Nissan, KIA, Mercedes have allowed the firms to dominate the production and distribution of their cars in ASEAN region.

Finally the establishment of ASEAN Free Trade Area (AFTA) paved away the benefits of location advantages ASEAN firms. Firms routinely compare economic and non-economic characteristics of the home market with those of the foreign market in determining where to locate their production facilities. If home country production is found to be more desirable than host country production, the firm will choose to enter the host country market via exporting. For example, Siam Cement, one of the world's lowest-cost producers, has relied on exports from it modern Thailand factories to serve the Cambodian, Vietnam, and Laotioan markets rather than setting up production facilities in those countries (WTO, 2015).

\section{ASEAN Economic Community: Firm Perspectives}

As noted in the previous section, the main criterion for a firm to invest in a foreign country is purely based on risks and returns. In the case of FDI flows into ASEAN region, risk and returns were compensated by firm's possession 
of proprietary assets which are normally embedded in these firms. It has been suggested that the kind of factors which have been found to link with the ownership-specific assets are those such as skills, managerial complexity, capital intensity, technical intensity and innovative capability (Mohamad, 2012). It is further observed that these factors which are seen to cause the formation of the multinational corporations are commonly found to be the outcome of the firms' structural, conduct and performance within the industry. This section reports on the profile of the firms and industries that have operations in ASEAN.

From our qualitative surveys and analyses of the macro economic conditions of ASEAN countries we have found that there are similarities of the characteristics of the method of internationalization among ASEAN's firms. These characteristics were found to be the existence of high firms and industrial concentration in terms of one aspect of internationalization mode as compared to the other. Internationalization is prevalent that exporting is more preferable as compared to licensing or franchising though there are resembles of joint venture activities. Exporting is generally recognized as being the least-risk method of internationalization and, as such, normally represents the beginning of an international operation of a firm. It is estimated that in 2015 a total value of USD 2512 billion is in the form of merchandise trade among ASEAN member countries (Table 4.0).

Table 4.0

\section{Merchandise Trade of ASEAN}

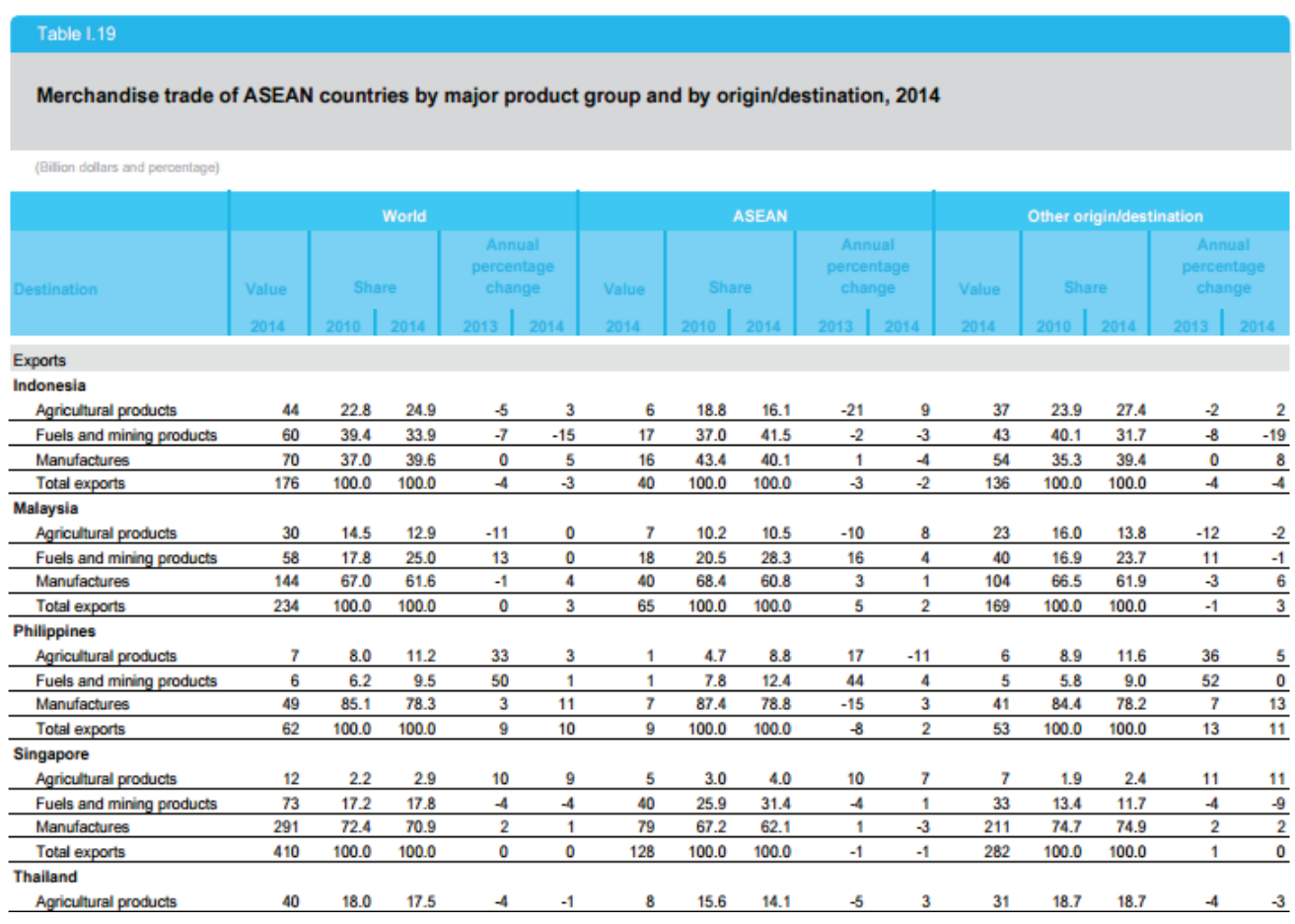




\begin{tabular}{|c|c|c|c|c|c|c|c|c|c|c|c|c|c|c|c|}
\hline Fuels and mining products & 15 & 6.2 & 6.6 & -2 & -13 & 9 & 15.6 & 15.8 & -2 & -8 & 6 & 3.5 & 3.3 & -2 & 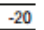 \\
\hline Manufactures & 170 & 72.5 & 74.7 & 3 & 1 & 41 & 68.7 & 68.5 & 6 & 3 & 129 & 73.6 & 76.9 & 2 & 1 \\
\hline Total exports & 228 & 100.0 & 100.0 & 0 & 0 & 59 & 100.0 & 100.0 & 5 & 0 & 168 & 100.0 & 100.0 & -2 & -1 \\
\hline \multicolumn{16}{|l|}{ ASEAN } \\
\hline Agricultural products & 164 & 12.6 & 12.6 & -3 & 3 & 32 & 9.8 & 9.8 & -8 & 6 & 131 & 13.5 & 13.6 & -1 & 2 \\
\hline Fuels and mining products & 239 & 18.6 & 18.4 & -1 & -6 & 96 & 25.4 & 29.1 & 2 & 0 & 142 & 16.3 & 14.8 & -3 & -10 \\
\hline Manufactures & 850 & 65.2 & 65.7 & 4 & 4 & 197 & 63.0 & 59.5 & 3 & -1 & 654 & 65.9 & 67.8 & 4 & $\frac{6}{6}$ \\
\hline Total exports & 1295 & 100.0 & 100.0 & 2 & 2 & 331 & 100.0 & 100.0 & 2 & 0 & 965 & 100.0 & 100.0 & 1 & 2 \\
\hline \multicolumn{16}{|l|}{ Imports } \\
\hline \multicolumn{16}{|l|}{ Indonesia } \\
\hline Agricultural products & 22 & 11.5 & 12.5 & 3 & 3 & 3 & 6.2 & 5.6 & -28 & 4 & 19 & 13.7 & 15.2 & 10 & \\
\hline Fuels and mining products & 50 & 23.8 & 27.9 & 5 & -3 & 22 & 40.5 & 43.1 & 7 & -11 & 28 & 17.0 & 21.9 & 4 & 3 \\
\hline Manufactures & 105 & 63.2 & 58.7 & -6 & -6 & 26 & 53.1 & 51.0 & -1 & -2 & 79 & 67.3 & 61.8 & -8 & -8 \\
\hline Total imports & 178 & 100.0 & 100.0 & -3 & -5 & 51 & 100.0 & 100.0 & 0 & -6 & 127 & 100.0 & 100.0 & -4 & -4 \\
\hline \multicolumn{16}{|l|}{ Malaysia } \\
\hline Agricultural products & 20 & 9.8 & 9.7 & -7 & 1 & 7 & 15.1 & 13.0 & -18 & -3 & 13 & 7.8 & 8.5 & 1 & \\
\hline Fuels and mining products & 47 & 15.1 & 22.5 & 21 & 3 & 17 & 24.0 & 32.3 & 8 & -2 & 30 & 11.8 & 19.1 & 31 & 6 \\
\hline Manufactures & 137 & 73.3 & 65.8 & 2 & 1 & 29 & 59.4 & 53.0 & 1 & -1 & 109 & 78.5 & 70.2 & 2 & 2 \\
\hline Total imports & 209 & 100.0 & 100.0 & 5 & 1 & 54 & 100.0 & 100.0 & 0 & -2 & 155 & 100.0 & 100.0 & 7 & 3 \\
\hline \multicolumn{16}{|l|}{ Phillippines } \\
\hline Agricultural products & 9 & 11.7 & 12.8 & -1 & 21 & 3 & 16.7 & 15.6 & -10 & 46 & 6 & 9.7 & 12.0 & 2 & 13 \\
\hline Fuels and mining products & 15 & 20.7 & 21.8 & -5 & -5 & 3 & 24.9 & 18.8 & -9 & 4 & 12 & 19.1 & 22.7 & -4 & -7 \\
\hline Manufactures & 44 & 66.8 & 65.0 & 2 & 4 & 11 & 57.9 & 65.2 & -3 & 11 & 33 & 70.2 & 65.0 & 3 & 2 \\
\hline Total imports & 68 & 100.0 & 100.0 & 0 & 4 & 16 & 100.0 & 100.0 & -5 & 14 & 51 & 100.0 & 100.0 & 1 & \\
\hline \multicolumn{16}{|l|}{ Singapore } \\
\hline Agricultural products & 15 & 3.5 & 4.0 & 3 & 2 & 5 & 5.8 & 7.2 & -6 & 3 & 9 & 2.8 & 3.2 & 8 & 2 \\
\hline Fuels and mining products & 120 & 27.6 & 32.8 & -5 & -2 & 25 & 22.1 & 33.5 & 1 & -6 & 95 & 29.3 & 32.6 & -7 & -1 \\
\hline Manufactures & 225 & 64.9 & 61.3 & 1 & -2 & 43 & 64.3 & 57.3 & -4 & -2 & 181 & 65.1 & 62.4 & 2 & -1 \\
\hline Total imports & 366 & 100.0 & 100.0 & -2 & -2 & 75 & 100.0 & 100.0 & -2 & -3 & 291 & 100.0 & 100.0 & -2 & -1 \\
\hline \multicolumn{16}{|l|}{ Thailand } \\
\hline Agricultural products & 16 & 6.6 & 7.1 & -2 & -2 & 3 & 6.2 & 6.8 & -11 & 5 & 13 & 6.6 & 7.2 & 0 & -4 \\
\hline Fuels and mining products & 56 & 22.0 & 24.8 & 6 & -7 & 14 & 27.3 & 31.3 & 5 & 0 & 43 & 20.8 & 23.2 & 7 & -10 \\
\hline Manufactures & 148 & 66.8 & 65.1 & -4 & -6 & 27 & 65.6 & 61.4 & 3 & -3 & 122 & 67.0 & 66.0 & -5 & -7 \\
\hline Total imports & 228 & 100.0 & 100.0 & 1 & -9 & 43 & 100.0 & 100.0 & 3 & -2 & 185 & 100.0 & 100.0 & 0 & -11 \\
\hline \multicolumn{16}{|l|}{ ASEAN } \\
\hline Agricultural products & 103 & 7.7 & 8.3 & 1 & 5 & 27 & 9.6 & 9.7 & -11 & 7 & 76 & 7.1 & 7.9 & 7 & 4 \\
\hline Fuels and mining products & 311 & 22.0 & 25.2 & 2 & -2 & 92 & 27.0 & 33.0 & 3 & -4 & 219 & 20.4 & 22.9 & 2 & -1 \\
\hline Manufactures & 800 & 67.4 & 64.8 & 1 & 0 & 156 & 60.3 & 56.3 & 1 & 0 & 644 & 69.6 & 67.3 & 2 & \\
\hline Total imports & 1235 & 100.0 & 100.0 & 2 & -1 & 278 & 100.0 & 100.0 & 0 & -1 & 957 & 100.0 & 100.0 & 2 & \\
\hline
\end{tabular}

Of this figure, USD 1295 billion is in the form of export and the rest is import. The explanation of the reason why export is more preferable to the ASEAN firms may be viewed from several economic perspectives. Unlike multinational corporations from developed countries where their strength are in their resources and usage of capital-intensive technology, the firms from developing countries are smaller, used labor-intensive technology and produced unbranded low R \& D, low quality products that compete on the basis of price in developing countries. However, these embedded characteristics of the developing countries firms may not be that strong to offset the possibilities of additional costs of operating on shores but significantly capable of competing through offshore operations. Hence, the choice of internationalization of the firms in the developing countries now rest in the form of exports.

The other two modes of internationalization such as licensing and franchising seem to be obscure and of no significant to the ASEAN firms. There is an obvious explanation for the absence of such methodologies. The industry which is characterized with high licensing activities is normally associated with the type of industry that produces consumer products which undergo tremendous amount of research and development activities. One of the common type is the pharmaceutical industry. In the developed countries, pharmaceutical firms routinely use licensing as their entry mode. One of the specific feature of this 
industry is that the product is patented in view of the unique medical properties and the requirement for good distribution of local networks. Obtaining either is an expensive venture. Researching, developing, and testing a new wonder drug can cost several hundred million dollars, while distribution networks must be large to be effective. Many such firms prefer to forgo the expensive and time-consuming process of setting up overseas production facilities and foreign distribution networks. Instead they grant existing local firms the right to manufacture and distribute the patented drug in return for royalty payments.

Perhaps the other mode of internationalization of ASEAN firms which is gaining momentum and may become the significant channel of international operation in the future is foreign direct investment. It is noted that foreign direct investment by member countries of ASEAN is growing rapidly, initially at lower rates but however progressing rapidly in current years. Another interesting feature of foreign direct investment is the growing concern among member countries to invest within ASEAN region besides the traditional countries of the developed nations. One important feature was exhibited that comes from this operation. At first glance, developing countries' multinational corporations do not possess proprietary skills or knowledge in management, technology, or marketing skill comparable to their counterparts from the developed countries. The products of the developing countries' multinational corporations did not compete directly against those of other multinational corporations but were specifically directed to home countries and other countries within the economic realm of the parent companies. This is so because developing countries' firms did not have access to the latest technology, the large amount of capital or expertise necessary for large-scale, capital-intensive technology and hence must be able to introduce appropriate products suitable to such markets. Therefore the suitability of developing countries foreign direct investment rests on the ability of the firm to produce goods or joint venture projects at lower cost, or the ability to operate at smaller scale with simpler application and usage of flexible technologies.

Table 5.0

ASEAN Total Trade, Intra-ASEAN and Extra-ASEAN Trade, 2006-2013

(in USȘ Million)

\begin{tabular}{|c|c|c|c|c|c|c|c|c|}
\hline Country & 2006 & 2007 & 2008 & 2009 & 2010 & 2011 & 2012 & 2013 \\
\hline (1) & (2) & (3) & (4) & (5) & (6) & (7) & (8) & (9) \\
\hline \multicolumn{9}{|l|}{ Total Trade } \\
\hline Brunei Darussalam & $9,108.3$ & $9,749.9$ & $12,774.7$ & $9,602.5$ & $10,999.2$ & $14,822.3$ & $16,856.3$ & $15,057.2$ \\
\hline Cambodia & $6,437.4$ & $7,580.6$ & $8,775.5$ & $8,886.7$ & $10,480.3$ & $12,844.1$ & $18,663.7$ & $18,324.2$ \\
\hline Indonesia & $161,864.1$ & $188,574.3$ & $266,217.7$ & $213,339.2$ & $293,442.4$ & $380,932.3$ & $381,721.3$ & $369,180.5$ \\
\hline Lao PDR & 990.2 & $1,093.0$ & $2,630.9$ & $2,962.1$ & $4,509.1$ & $3,955.9$ & $6,158.8$ & $5,884.9$ \\
\hline Malaysia & $285,542.9$ & $323,116.0$ & $338,794.7$ & $280,221.4$ & $363,534.3$ & $415,559.1$ & $423,930.3$ & $434,228.7$ \\
\hline Myanmar & $5,630.2$ & $8,722.5$ & $10,415.4$ & $10,191.3$ & $11,798.3$ & $14,925.1$ & $18,503.3$ & $23,445.4$ \\
\hline Philippines & $99,183.8$ & $105,979.5$ & $105,671.0$ & $83,868.6$ & $109,660.3$ & $111,751.6$ & $117,381.6$ & $119,108.9$ \\
\hline Singapore & $510,516.7$ & $562,451.2$ & $657,985.8$ & $515,616.3$ & $662,658.2$ & $775,167.2$ & $788,116.9$ & $783,265.5$ \\
\hline Thailand & $248,688.3$ & $293,536.8$ & $352,534.2$ & $286,266.8$ & $385,040.8$ & $458,904.4$ & $477,301.9$ & $478,247.3$ \\
\hline Viet Nam & $77,270.5$ & $109,982.5$ & $141,357.0$ & $125,921.9$ & $156,993.1$ & $199,582.1$ & $227,793.3$ & $264,774.0$ \\
\hline TOTAL & $1,405,232.5$ & $1,610,786.3$ & $1,897,157.1$ & $1,536,876.8$ & $2,009,115.9$ & $2,388,444.0$ & $2,476,427.4$ & $2,511,516.5$ \\
\hline
\end{tabular}


As for regional and individual member country analyses, some important dimensions can be observed in Table 4.0 and Table 5.. Most ASEAN exports are directed outside the region The US, Japan and the European Union (EU) have been the traditional markets. More recently, the destination of exports has become more broadly based with inclusion of other developing countries. These countries will remain important new markets. This is evident from the fact that exports to China have grown double the pace of total exports in 1990 to 2015 and similarly exports to Singapore, Taiwan and Middle East countries.

The other change in ASEAN's trade pattern is the emergence of the ASEAN market itself. For many years, exports to the rest of the world grew at a rate much faster than that of intra-ASEAN exports, which reflected a low level of economic integration among ASEAN members despite their geographic proximity. From 2003 to 2013 (Table 4.0), intra-ASEAN trade grew with a steady pace with an average growth of $7.6 \%$ trade with the rest of the world, maintaining a share of slightly under 20 percent of the total trade. Since 2000, the growth rate of intra-ASEAN exports exceeded that of other exports by a small margin. In 2013, ASEAN exports were recorded at USD 1295 billion while imports were USD 1235 billion.

The composition of ASEAN exports has also undergone a remarkable change over the past 20 years. There has been a big shift from agricultural commodities to manufactured goods. As shown in Table 4.0, manufacturing sector, particularly elaborately transformed manufactures, now dominate ASEAN's merchandise trade. Structural change has transformed a number of ASEAN economies from being exporters of agricultural commodities and unprocessed goods into exporters of light manufactures. Although intra-ASEAN trade has increased in recent years, this trend should not be overstated. The ASEAN economies' level of integration remains well below potential. Some 75 percent of intra-ASEAN trade originates from Singapore, the region's entre port and most open economy, where non ASEAN goods, especially crude oil and petroleum, are re-exported to countries inside the region. If crude oil and petroleum products are omitted, intra-ASEAN trade is only 5 percent of total ASEAN exports. It is also noted that among the top 50 corporations in ASEAN, a high percentage of them were having their core business in oil-related activities with an accumulative export of USD 239 billion while the import value of USD 311 for the 2014.

WTO reported that Singapore's inflationary pressures are falling while the wage rises are moderating with its rate of GDP growth for 2014 was 7.0 percent. Export growth was about 20 percent though it has been said that there was a decline in manufacturing strength as foreign investors shun Singapore for cheaper location especially in other ASEAN countries and China. From Table 4.0 
and Table 5.0, it is noted that Singapore total trade have grown from USD 272 billion in 2003 to USD 856 billion in 2013. Singapore top trading partners are traditional developed countries at USD 410 billion, ASEAN at USD 128 billion and others at USD 282 billion in 2014. Singapore intra-industry trade among the top 13 products consists mainly of electronic goods with the exception of refined petroleum products, polymerization and natural rubber latex. The top 13 product groups, which represent 50.48 percent of Singapore's intra-industry trade, shows at Singapore's intra-industry trade is widely dispersed among the product groups.

Table 4.0 and Table 5.0 show Malaysia trade performances for the year 2003 and 2013. Malaysia's total exports and imports registered at USD 99.4 billion and USD 81.9 billion respectively in 2003 and grew to USD 234 billion in its export and the imports of USD 209 billion in 2013. Malaysia's leading export item were electronic and manufacturing products followed by oil and gas and palm oil products while its leading imports are machinery and transport equipment, manufactures goods and chemicals. Malaysia's major ASEAN trading partners are Singapore with export figure of USD12.43 billion followed by Thailand with USD2.27 billion, Indonesia with USD730 million and Philippines with USD624 million while its import from Singapore was USD8.6 billion, Thailand USD1.51 billion, Indonesia USD961 million and Philippines at USD328 million. Malaysia's export promotion policies which place greater emphasis on free trade zones and licensed manufacturing warehouses, have resulted in a high concentration of "sub-contracting" types of goods in its intra-industry trade. Malaysia is still heavily dependent on foreign investment in order to spearhead the industrialization process. Despite the emergence of the cheaper production bases of the new emerging market economies such as China and Vietnam, foreign proposed investments in Malaysia registered a total value of USD 17.056 billion in 2013. About. a quarter of foreign investment were in the electronic and electrical goods sector, where companies from US, Japan and Taiwan predominate. The heavy foreign investment in electronics pushed up the growth in the manufacturing sector. Malaysian companies have also started to invest outside Malaysia particularly in other ASEAN countries and China in the construction, infrastructure and real estates and property development sectors. The figures for this category of investment stood at USD 6.604 billion in 1996.

Thailand recorded steady growth in her total trade. The value of Thailand total trade was USD 248.6 billion in 2006 and increased to USD 478.2 in 2013 (Table 6.0 ). The volume of trade between Thailand other ASEAN countries increased from USD 16.54 billion in 2003 to 102 billion in 2014 with export outnumbered import throughout the years. Thailand major trading partner was to Singapore 
apart from other ASEAN countries while China is now becoming the main trading nation of ASEAN. The items of trades were mainly petroleum, electronic products and the electrical machinery and parts. Thailand's intra-industry trade consists of a broader range of products. With the new inclusion of petroleum, intermediate goods such as electronic, transistors and valve absorb a large share of Thailand's intra-industry trade. Also play an important role in intra-trade is precious and semi-precious stones and textile yarn. Thailand's economy has been in its down turn lately following the decrease in its currency and it is envisaged that once the crisis is over the economy will be on the smooth track again.

Table 6.0

\section{World Statistics}

\section{Table I.1. Growth rates of global GDP, GFCF, trade, employment and FDI, 2008-2016}

\begin{tabular}{|c|c|c|c|c|c|c|c|c|c|}
\hline Variable & 2008 & 2009 & 2010 & 2011 & 2012 & 2013 & 2014 & $2015^{a}$ & $2016^{a}$ \\
\hline GDP & 1.5 & -2.0 & 4.1 & 2.9 & 2.4 & 2.5 & 2.6 & 2.8 & 3.1 \\
\hline Trade & 3.0 & -10.6 & 12.6 & 6.8 & 2.8 & 3.5 & 3.4 & 3.7 & 4.7 \\
\hline GFCF & 3.0 & -3.5 & 5.7 & 5.5 & 3.9 & 3.2 & 2.9 & 3.0 & 4.7 \\
\hline Employment & 1.2 & 1.1 & 1.2 & 1.4 & 1.4 & 1.4 & 1.3 & 1.3 & 1.2 \\
\hline FDI & -20.4 & -20.4 & 11.9 & 17.7 & -10.3 & 4.6 & -16.3 & 11.4 & 8.4 \\
\hline \multicolumn{10}{|l|}{ Memorandum } \\
\hline FDI value (in \$ trillions) & 1.49 & 1.19 & 1.33 & 1.56 & 1.40 & 1.47 & 1.23 & 1.37 & 1.48 \\
\hline
\end{tabular}

Indonesia's economy has been improving very much due to support from foreign investment in its development whereby investment commitment from abroad doubled from USD 35 billion in 2003 to almost USD 78 billion in 2014. Much of the foreign investment in the past few years has been aimed at export-oriented industry as Indonesia's policy switch from energy reliance to manufacturing-based economy. It is noted from Table 4.0 and Table 5.0 that Indonesia's total trade was recorded at USD 161.8 billion in 2006 and increased to USD 369.1 billion in 2013. In-term of total trade, ASEAN countries are the primary trading partners followed by developed countries in more recent cases is the advent of China as new economic force in the region. The product groups that contributed the most towards Indonesia's intra-industry trade contrasts the both Malaysia and Thailand with the conspicuous presence of petroleum oils and petroleum products. With electronic products play a minor role, the type of goods involved in Indonesia's intra-industry trade represent mainly processed fuels and lubricants, and processed industrial supplies which are classified as intermediate goods. 
Table 7.0

FORTUNE GLOBAL 500

\begin{tabular}{|c|c|c|c|c|c|c|}
\hline Fanking * & Nams & Inductry & Revenus (U aD billione) * & As of: & Revenus growth * & Employesce. \\
\hline 1 & Wel-1hat atores, inc. & Fetal & $\$ 482$ & Janugry 2016 & $\nabla 0.7 \%$ & $2.200,000$ \\
\hline 2 & ainopec Grovs & Oll and gas & 3455 & 2014 & $\mathbf{\nabla} 1.7 \%$ & 358.57 \\
\hline 3 & Caind Natonal Fetoleum Corporation & Oll and gas & $\$ 428$ & 2014 & $\nabla 1.1 \%$ & $1,636.532$ \\
\hline 4 & asudi Arameo & Oll and gas & 5338 & 2014 & $\Delta 6.2 \%$ & 60.000 \\
\hline 6 & atase Grd & Electic ublity & 5333 & 2014 & $\Delta 8.9 \%$ & $1,564,000$ \\
\hline 8 & asmaung & Conglomerase & 5305 & 2014 & $\mathbf{v} 7.2 \%$ & 439,000 \\
\hline 7 & Foyal Dusch anell & Oll and gas & 3273 & 2015 & $\nabla 7.2 \%$ & 94,000 \\
\hline 8 & Exxommobll & Oll and gas & 3268 & 2015 & $\nabla 7.2 \%$ & 75,300 \\
\hline 8 & veol & Commodives & 3270 & 2014 & $\boldsymbol{\nabla} 13.7 \%$ & 5,44 \\
\hline 10 & Kuwe: Fetoletum Corporation & Oll and gas & 5252 & 2014 & $\triangle 8 \%$ & 45,000 \\
\hline 11 & Volkswgegen & Automosve & 5245 & 2014 & $\triangle 28 \%$ & 572.800 \\
\hline 12 & Aosie & Consumer electionics & 3234 & 2015 & $\triangle 28 \%$ & 115,000 \\
\hline 13 & Toyots & Automobve & 5227 & March 31, 2015 & $\triangle 6.0 \%$ & 344,109 \\
\hline 14 & gp & Oll and gas & 3223 & 2015 & V $37.9 \%$ & 83.900 \\
\hline 16 & Gencore & Commodites & 5221 & 2014 & $\nabla 5.3 \%$ & 181,000 \\
\hline 18 & Total & Oll and gas & 5212 & 2014 & $\boldsymbol{\nabla} 11.5 \%$ & 100.307 \\
\hline 17 & Beskshire Hongwoy & Conglomerate & 3211 & 2015 & $48.3 \%$ & 316,000 \\
\hline 18 & McKesson & Fhemgceutcals & $\$ 179$ & March 31, 2015 & $\triangle 30.1 \%$ & 32.000 \\
\hline 18 & Coins Ralwey & Transapot & $\$ 163$ & 2014 & $\mathbf{V} 4.7 \%$ & $2.045,600$ \\
\hline 20 & Frillos 66 & Oll and gas & $\$ 161$ & 2014 & $\boldsymbol{\nabla} 6.4 \%$ & 13.500 \\
\hline 21 & Jasen Fost & Conglomerate & 5157 & March 31, 2015 & $\boldsymbol{V} 69 \%$ & 229,000 \\
\hline 22 & Daimier & Automobve & $\$ 157$ & 2014 & $\triangle 10.1 \%$ & 275,087 \\
\hline 23 & Generg/ Mobos & Automorve & 3152 & 2015 & $\nabla 1.7 \%$ & 284,000 \\
\hline 24 & General Electic & Conglomerats & $\$ 149$ & 2014 & $\Delta 1.7 \%$ & 305,000 \\
\hline 26 & Exor & Financial sevices & $\$ 148$ & 2014 & $\triangle 7.8 \%$ & 318.563 \\
\hline $2 a$ & Alllanz & Fingncial sevices & $\$ 148$ & 2014 & $\triangle 10.4 \%$ & $147,42:$ \\
\hline 27 & Ford Mobor Comosny & Automobve & $\$ 144$ & 2014 & $\nabla 20 \%$ & 164,000 \\
\hline 28 & Pevobras & Oll and gas & $\$ 144$ & 2014 & $\Delta 1.6 \%$ & 86,11 \\
\hline 28 & Luxoll & Oll and gas & $\$ 144$ & 2014 & $\Delta 19 \%$ & 120,000 \\
\hline 30 & Honda & Automobve & $\$ 142$ & 2014 & $\triangle 20.0 \%$ & 198,56 \\
\hline 31 & CVa Heath & Retall & $\$ 139$ & 2014 & $\triangle 9.9 \%$ & 208,000 \\
\hline 32 & Crevion & Oll and gas & $\$ 138$ & 2015 & $\mathbf{T} 349 \%$ & 64,700 \\
\hline 33 & Induatisl and Commercisl asek of Coing & Financial sevices & 3137 & 2014 & $\triangle 10.89$ & 405,35 \\
\hline 34 & EON & Electic ubilty & $\$ 135$ & 2014 & $\boldsymbol{\nabla} 9.8 \%$ & 79,000 \\
\hline 35 & Foxcom & Electronics & $\$ 133$ & 2014 & $\triangle 6.6 \%$ & $1,290,000$ \\
\hline 39 & Ent & Oll and gas & $\$ 133$ & 2014 & $\boldsymbol{\nabla} 4.4 \%$ & 82.289 \\
\hline 37 & ATST & Telecommunlcavors & $\$ 132$ & 2014 & $\triangle 29 \%$ & 256,000 \\
\hline 38 & velero & Oll and gas & $\$ 131$ & 2014 & $\nabla 5.5 \%$ & 22.000 \\
\hline 38 & Unilted Healon & Heath care & $\$ 131$ & 2014 & $\triangle 6.5 \%$ & 99,000 \\
\hline 40 & POVIAA & Oll and gas & $\$ 128$ & 2014 & $\nabla 4.4 \%$ & 121,000 \\
\hline 41 & Tratgura & Commodites & $\$ 128$ & aepbember 30,2014 & $\nabla 0.4 \%$ & 5.328 \\
\hline 42 & vetizon & Telecommunicasons & $\$ 127$ & 2014 & $\Delta 5.4 \%$ & 176,000 \\
\hline 43 & Coins Constuetion Engineeting & Constuction & $\$ 125$ & 2014 & $\triangle 17.3 \%$ & 216.82 \\
\hline 44 & cagill & Food processing & $\$ 120$ & May 31, 2015 & $\boldsymbol{\nabla} 120 \%$ & 158,000 \\
\hline 45 & Ameisourcesergen & Fhamaceutcals & $\$ 120$ & aescember 30,2014 & $\triangle 3599 \%$ & 14.500 \\
\hline 49 & Koch indusaties & Conglomerate & 5115 & 2014 & $4.5 \%$ & 100,000 \\
\hline 47 & Costco & Fetall & $\$ 113$ & 2014 & $\Delta .1 \%$ & 189,000 \\
\hline 48 & Hewenfackard & Electronics & $\$ 111$ & October 31, 2014 & $\nabla 0.8 \%$ & 302.000 \\
\hline 48 & Tata Grovp & Conglomerate & 5108 & 2015 & $\triangle 5.3 \%$ & 611,000 \\
\hline
\end{tabular}

The high tariff barriers among individual member countries may not be a good strategy for regional economic growth, and the fact that the countries' largely export the same type of commodities and compete with each other will further detriment any possible growth and development of trade within the region. Competition, motivated by individual nation-building priorities and the consequent low level of specialization may continue to create a region of low industrial, complementarily. If economic integration is to progress, steps have to be taken to reverse this situation. Removal of barriers to imports from ASEAN 
member will foster intra-ASEAN trade. It is interesting to note that ASEAN is moving towards ASEAN community in full fledge. The results will be expansion of regional trade and acceleration of business growth.

In the case of corporate performance for the region, in 2015, it was estimated that about 20 companies from ASEAN have the highest capitalization of over USD 20 billion (Nikkei, 2015) Detailed analysis is presented in Table 8.0.

Table 8.0

\section{ASEAN 100 LARGEST CORPORATIONS}

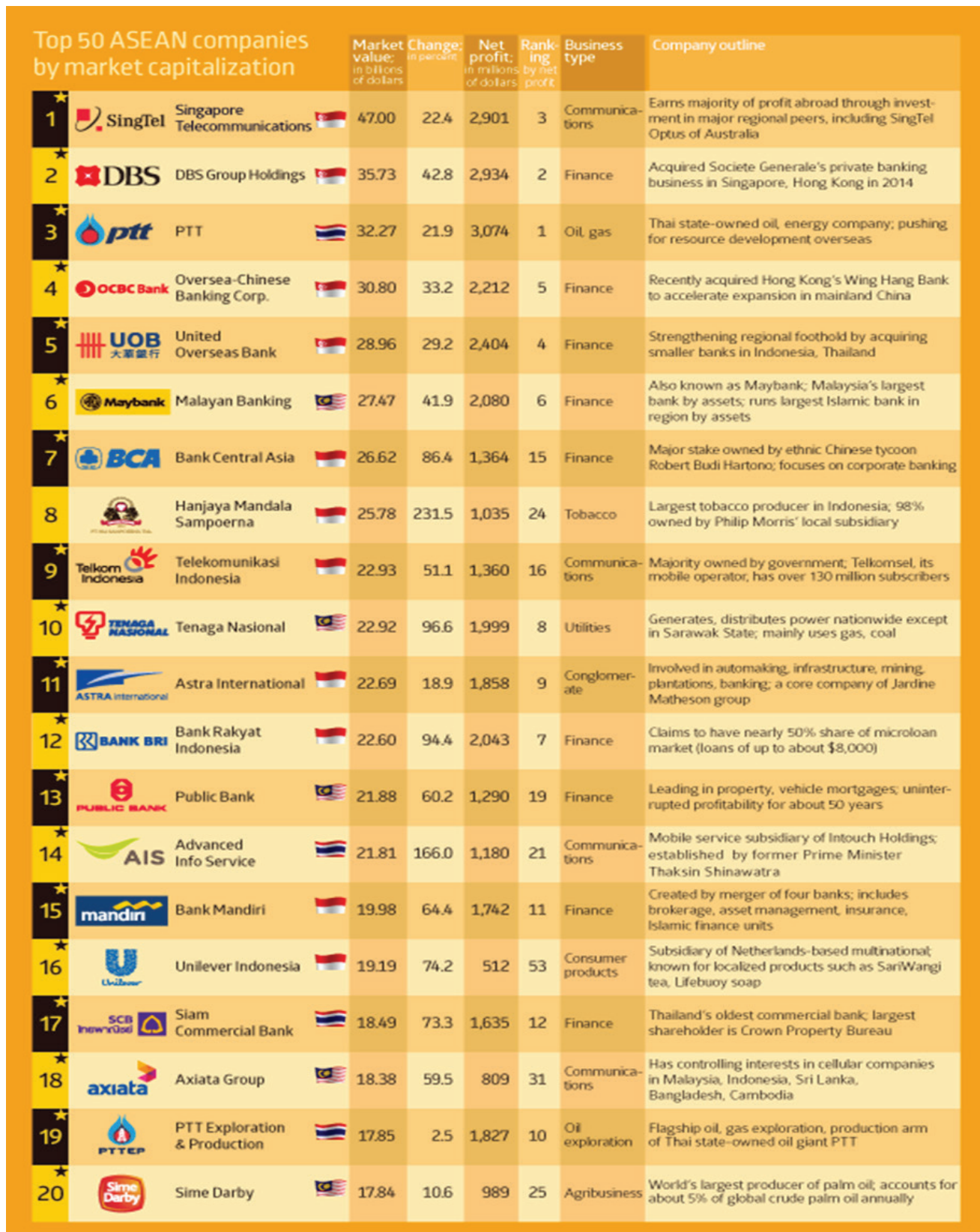

Yustisia Volume 8 Number 1 (January-April 2019)

Foreign Direct Investment Law ... $\quad \mathbf{6 5}$ 
The biggest company is Singapore Telecommunications with the capitalization value of USD 47.00 billion. The other largest companies come mostly from multinational firms in oil and gas and financial services. Singapore companies dominated the figures followed by Thailand, Malaysia and Indonesia as presented in Table 8.0. The highest profit was recorded by PTT of Thailand at 3.074 billion while for non-oil and non- financial services was recorded by Singapore Telecommunication at 2.901 billion. From these 100 ASEAN companies, 19 companies involved in oil refining, marketing and trading. Seven companies involved in the car assembly and sales, 6 companies involved in the consumer electronic sector and the rest are involved in various sectors such as air transport, shipping, property and real estates, telecommunication and others. Also, it is interesting to be noted that from these 100 ASEAN companies, 25 companies were originally foreign companies that were mainly involved in the oil trading business and electronic components sectors. One particular explanation for this occurrence could probably be explained by their global business strategy of implementing contractual joint venture foreign direct investment. The original companies will not be losing their interests with the ownership and control remain with the parent firm while at the same time extend their global operation and continue to receive benefits of local resources.

\section{E. CLOSING}

The analysis of foreign direct investment flows and the development of ASEAN Economic Community has been approached from a different direction, namely, that of stages of single market integration. Generally we have found that FDI flows had significant impact on ASEAN intraregional trade and the initiatives taken by the leaders of ASEAN enhanced cross-border collaboration among the various capital markets in ASEAN, including by building capacity and infrastructure. FDI flows to ASEAN amounted to a record high of USD 120 billion. Moreover, at almost 9 percent of world FDI inflows, ASEAN's share of global FDI is back to the level during boom years preceding the Asian financial crisis. The trend of rising FDI inflows, in USD terms and in the relative terms, applies equally to the group of ASEAN-4 countries (Indonesia, Malaysia, the Philippines, and Thailand), Singapore and the group 5 other ASEAN countries (Vietnam, Cambodia, Myanmar, Laos and Timor Lestie). Rising trend was recorded from FDI flows from China, Japan and Korea as well as from United States and Malaysia and Singapore. Several factors may be helping to make ASEAN an attractive investment market and becoming ASEAN Economic Community. Wage costs in manufacturing in ASEAN have been declining relative 
to China owing to divergent demographics and exchange rate movements. The favorable trend in relative wage costs is expected to continue in the coming years, reflecting stronger labor force growth in ASEAN. Geopolitical considerations and ASEAN's growing middle class could be also drive more FDI and lastly, ASEAN's commitment to further reduce trade and investment barriers will accelerate a single market formation the future.

\section{BIBLIOGRAPHY}

\section{Books:}

Buckley, P.J., Casson, M.C, 1976, The Future of the Multinational Enterprises, New Yor: Macmillan and Holmes Meier

Buckley, P.J, 1982, The Role of Exporting in the Market Servicing Plocies of Multinational Enterprises : Theoretical and Empirical Perspectives, in Czinkota, M.R. and Tesar, G. (eds) Export Management: An International Context. New York: Praeger

Caves, R. E, 1971, Multinational Enterprise and Economic Analysis, Cambridge: MIT Press

Caves. R. E, 1974, Multinational firms, competition and productivity in host-country markets. Economica, 41, May

Chandler, A. D, 1970, The growth of the transnational industrial firm in the United States and the United Kingdom. Economic History Review, 33, Series 2

Fortune Magazine, 2015, Global 500. New York: Time Inc

Kindleberger, C. P, 1969, American business abroad: Six lectures on direct investment. New Haven; Yale University Press.

Lall, S, 1976. Financial and profit performance of multinational corporations in developing countries: Some evidence from Indian and Columbian samples. World Development 4

Lall, S, 1982, Export of Technology by Newly-industrializing Countries. Oxford: Oxford University Press

Mohamad, Mohamad Hanapi, 2012, The Antecedents of International Business Models, Professorial Lecture Series. Universiti Utara Malaysia

Nikkei Asian Review, 2014, ASEAN 100, Tokyo: Nikkei Inc

Stopford, John.M. \& Louis T. Wells, 1972. Managing the multinational enterprise: Organization of the firm and ownership of the subsidiaries. New York: Basic Books 
UNCTAD, 2005, Statistical Tables 2003, New York and Geneva : United Nations.

UNCTAD, 2006, Statistical Tables 2004. New York and Geneva: United Nations

World Bank, 2015, World FDI Flows, New York

World Trade Organization, 2016, World Trade Statistics, New York and Geneva, United Nations

\section{Journals:}

Anderson, Erin \& Hubert Gatigon, 1986, Modes of entry: A transaction cost analysis and propositions. Journal of International Business Studies, 17 (Fall)

Chandler, A. D, 1970, The growth of the transnational industrial firm in the United States and the United Kingdom. Economic History Review, 33, Series 2

Dunning, J. H, 1980, Toward an eclectic theory of international production: Some empirical tests. Journal of International Business Studies, 11(2), 9-22

Hymer, S. H. (1970). The efficiency (contradictions) of multinational corporations. American Economic Review, 60, 441-8

Teece, D. J. (1977). Technology transfer by multinational firms: The resource of international technology. Economic Journal, June

Vernon, R. (1966). International investment and international trade in the product cycle. Quarterly Journal of Economics, May, 190-207

Wells, L. T. (1968). A product life cycle for international trade? Journal of Marketing, 33, July 1-6

Werstphall, L.E, .Rhee,Y.W. and Purcell,G .(1979) Foreign influence on South Korean industrial development. Oxford Bulletin of Economics and Statistics41(4)

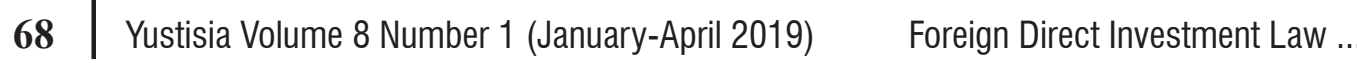

